JOURNAL OF SYNCHROTRON RADIATION

ISSN 1600-5775

Received 3 September 2020

Accepted 23 February 2021

Edited by I. Schlichting, Max Planck Institute for Medical Research, Germany

Keywords: SAXS; WAXS; undulators; beamlines.

Supporting information: this article has supporting information at journals.iucr.org/s

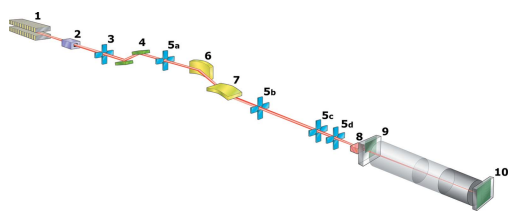

OPEN Ә ACCESS

\section{I22: SAXS/WAXS beamline at Diamond Light Source - an overview of 10 years operation}

\author{
A. J. Smith, ${ }^{\text {a }}$ S. G. Alcock, ${ }^{a}$ L. S. Davidson, ${ }^{a}$ J. H. Emmins, ${ }^{a}$ J. C. Hiller Bardsley, ${ }^{d}$ \\ P. Holloway, ${ }^{a}$ M. Malfois, ${ }^{c}$ A. R. Marshall, ${ }^{a}$ C. L. Pizzey, ${ }^{a}$ S. E. Rogers, ${ }^{b}$ \\ O. Shebanova, ${ }^{a}$ T. Snow, ${ }^{a}$ J. P. Sutter, ${ }^{a}$ E. P. Williams ${ }^{a}$ and N. J. Terrill ${ }^{\mathrm{a} *}$
}



Beamline I22 at Diamond Light Source is dedicated to the study of soft-matter systems from both biological and materials science. The beamline can operate in the range $3.7 \mathrm{keV}$ to $22 \mathrm{keV}$ for transmission SAXS and $14 \mathrm{keV}$ to $20 \mathrm{keV}$ for microfocus SAXS with beam sizes of $240 \mu \mathrm{m} \times 60 \mu \mathrm{m}$ [full width half-maximum $(\mathrm{FWHM})$ horizontal $(\mathrm{H}) \times$ vertical $(\mathrm{V})]$ at the sample for the main beamline, and approximately $10 \mu \mathrm{m} \times 10 \mu \mathrm{m}$ for the dedicated microfocusing platform. There is a versatile sample platform for accommodating a range of facilities and user-developed sample environments. The high brilliance of the insertion device source on I22 allows structural investigation of materials under extreme environments (for example, fluid flow at high pressures and temperatures). I22 provides reliable access to millisecond data acquisition timescales, essential to understanding kinetic processes such as protein folding or structural evolution in polymers and colloids.

\section{Introduction}

Small-angle X-ray scattering (SAXS) provides essential information on the structure and dynamics of large molecular assemblies in low-order environments. These are characteristic of living organisms and also many complex materials such as polymers and colloids. Relevant active research in the UK encompasses the fields of medicine (Ma et al., 2016; Burton et al., 2019; Coudrillier et al., 2016; Al-Jaibaji et al., 2018; Kudsiova et al., 2019), biology (Troilo et al., 2016; McGeehan et al., 2011; Arnold et al., 2011; Salamah et al., 2018), the environment (Neill et al., 2018; Seddon et al., 2016) and materials (Summerton et al., 2019; Wychowaniec et al., 2018; Burton et al., 2017), and includes studies of supramolecular organization in biomechanical systems (Xi et al., 2018; Kampourakis et al., 2018; Sui et al., 2014), corneal transparency (Morgan et al., 2018; Hayes et al., 2017), biological membranes (Barriga et al., 2016; Slatter et al., 2018; Tang et al., 2014), polymer processing (Stasiak et al., 2015; Wan et al., 2018; Heeley et al., 2013; Toolan et al., 2017), colloids (Calabrese et al., 2019; Poulos et al., 2016; Mable et al., 2016), inorganic aggregates (Raine et al., 2018; Bennett et al., 2015; Zhou et al., 2018), liquid crystals (Hallett et al., 2014; Prehm et al., 2018; Lehmann et al., 2018) and devices (Xia et al., 2018; Barrows et al., 2016).

\section{Beamline overview}

The scientific and technological challenges confronted by this diverse community required a high-resolution, high-brightness 
Table 1

Major components of I22.

\begin{tabular}{lll}
\hline $\begin{array}{l}\text { Fig. 1 } \\
\text { index }\end{array}$ & Component & $\begin{array}{l}\text { Distance from } \\
\text { source }(\mathrm{m})\end{array}$ \\
\hline 1 & In-vacuum undulator 25 mm period & 0.00 \\
2 & Customized aperture & 17.20 \\
3 & White beam slits & 22.70 \\
4 & Double-crystal monochromator (Si 111) & 24.00 \\
$5 \mathrm{a}-5 \mathrm{~d}$ & Monochromatic slits & $25.57,28.55,46.00,47.00$ \\
6 & Horizontal focusing mirror & 26.78 \\
7 & Vertical focusing mirror & 27.73 \\
8 & Sample position & 47.1 to 48 \\
9 & Wide-angle detector & 0.17 (from sample) \\
10 & Small-angle detector & 1.9 to 9.9 (from sample) \\
\hline
\end{tabular}

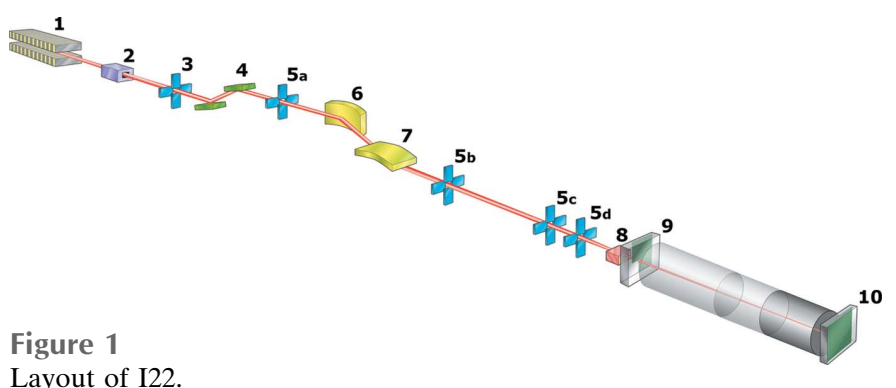

Layout of I22.

synchrotron beamline. The first small-angle scattering beamline at Diamond, I22 (see Fig. 1 and Table 1) uses an invacuum undulator source to deliver a high photon flux into a focused $240 \mu \mathrm{m} \times 60 \mu \mathrm{m}$ spot [full width at half-maximum $(\mathrm{FWHM})$, horizontal $(\mathrm{H}) \times \operatorname{vertical}(\mathrm{V})]$ at the sample for the main beamline, and approximately $10 \mu \mathrm{m} \times 10 \mu \mathrm{m}$ for a dedicated microfocusing platform. This platform will be the subject of a further technical paper, and will not be discussed in detail here. The main beamline has the potential for the continuous energy range $3.7 \mathrm{keV}$ to $22 \mathrm{keV}$ with, at present, the reduced range $14 \mathrm{keV}$ to $20 \mathrm{keV}$ for the microfocus option. It is currently operated from $7 \mathrm{keV}$ to $20 \mathrm{keV}$; lowerenergy operation would require either helium or vacuum sample chambers. Depending on the energy used, and the exact geometry of the scattering experiment, the $q$ range achievable at $\mathrm{I} 22$ is $0.0011 \leq q\left(\AA^{-1}\right) \leq 9.45$. The SAXS camera is composed of evacuated sections of flight tube with a nosecone incorporating the WAXS detector at the sample end and ended by a $310 \mathrm{~mm}$-diameter Kapton window at the SAXS detector end. These tubes can be connected as required to form camera lengths anywhere from $1.9 \mathrm{~m}$ to $9.9 \mathrm{~m}$ in $0.25 \mathrm{~m}$ steps. Changes to the configuration are manual so reconfiguration does take time, 20-60 min depending on camera length to be reconfigured. The vacuum achieved in the SAXS camera is $5 \times 10^{-5}$ mbar. The primary endstation, with associated area detectors for static and time resolved measurements, is capable of recording the scattered radiation from samples contained in a range of commercial and bespoke sample environments.

\section{Undulator}

The beamline operates a Diamond-designed (Patel et al., 2017) $2 \mathrm{~m}$ in-vacuum undulator with a period of $25 \mathrm{~mm}$,

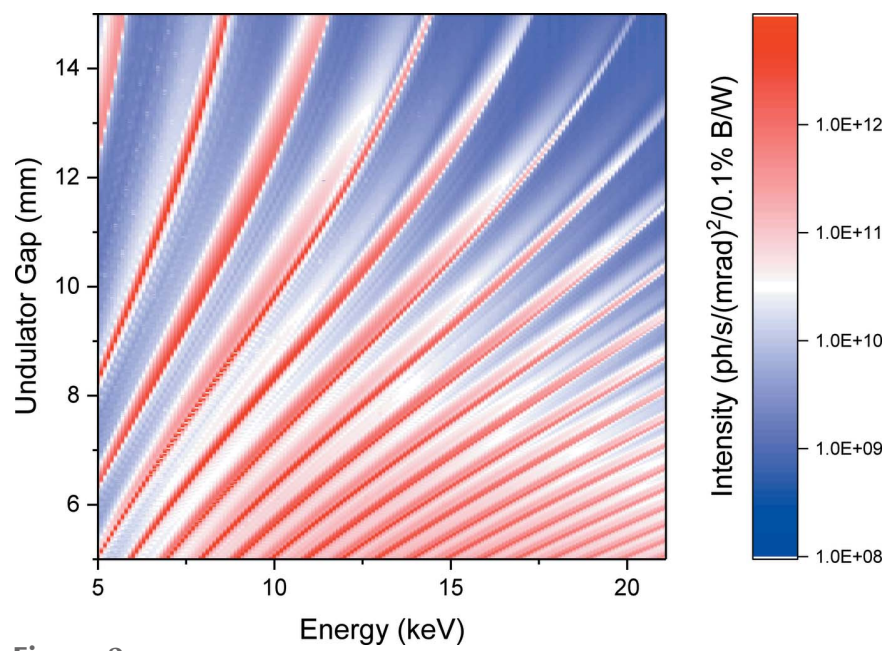

Figure 2

In-vacuum U25 undulator spectrum of I22. Flux values measured with calibrated diagnostic after the monochromator. NB: the primary white beam slits were closed to a central $100 \mu \mathrm{m} \times 100 \mu \mathrm{m}$ gap to give a clean undulator spectrum. Flux and undulator gap values at selected typical energies are reported in Table 3.

providing continuous energy coverage over the energy range of the beamline. The beamline is optimized for the energy range $8 \mathrm{keV}$ to $20 \mathrm{keV}$ working primarily with the 5th through to the 17 th harmonics. Off-axis undulator radiation is removed to minimize heat load on the beamline optics via a watercooled $150 \mu \mathrm{rad} \times 75 \mu \mathrm{rad}(\mathrm{H} \times \mathrm{V})$ aperture located inside the storage ring tunnel $17.202 \mathrm{~m}$ downstream from the source. Water-cooled primary slits further define the beam before energy selection and focusing. The undulator has a very small phase error $(0.02 \mathrm{~mm})$. Fig. 2 shows the spectrum as a function of energy and undulator gap. All available harmonics can clearly be distinguished, from the 2 nd at the top left, through to the 20th at the bottom right.

\section{Monochromator}

The monochromator (Oxford Danfysik, Oxford, UK) is a fixed-exit double-crystal design, originally established for three crystal sets. It is currently installed with an $\mathrm{Si}(111)$ crystal pair; this allows access over the full operational energy range, with a resolution of $1.6 \times 10^{-4} \Delta E / E$ at $10.0 \mathrm{keV}$. Vertical translation of the second crystal maintains a fixedbeam exit configuration for the beamline. Both the first and the second crystals are indirectly cooled by liquid nitrogen to prevent damage arising from the high power density of the undulator. An indium foil provides thermal contact for both crystals to a cooled copper block. The first crystal is cooled by liquid nitrogen flowing continuously through the copper block while heat from the second crystal is removed via copper braiding. The Diamond storage ring has run in top-up mode since October 2008, with an injection every $10 \mathrm{~min}$. This produces a very slight variation in ring current of $\sim 2 \%$ or $\pm 5 \mathrm{~mA}$ at most; therefore, changes in the heat load on the monochromator during an experiment are primarily due to undulator gap and harmonic changes associated with a change 
in energy. Both coarse motors $( \pm 4 \mathrm{mrad})$ and fine piezo actuators $( \pm 180 \mu \mathrm{rad})$ are used to adjust the pitch and roll of the crystals, maintaining alignment of the first and second crystal lattice planes.

\subsection{Monochromator calibration}

The monochromator is periodically calibrated using EXAFS spectra collected from a series of retractable metal foils that are permanently installed in the beamline downstream of the monochromator. Scatter diodes before and after the foils record $I_{0}$ and $I_{t}$ values, respectively. EXAFS features from the spectra (peaks), and the derivative of the spectra (edges) for all of the foils (V, Fe, $\mathrm{Cu}, \mathrm{Zn}, \mathrm{Au}, \mathrm{Zr}$, and Mo), are fitted, against their expected positions from literature values (Bearden \& Burr, 1967), in a global least-squares minimization. The main part (lower left) of Fig. 3 shows the overall fit. The lower right section of Fig. 3 shows the absorption spectra from $\mathrm{V}, \mathrm{Cu}, \mathrm{Au}$ and $\mathrm{Mo}$ as measured on $\mathrm{I} 22$. Expanded views of the linear fitting of the vanadium, copper, gold and molybdenum features are shown along the top, demonstrating the consistency of the fit across a wide range of Bragg angles. In a typical fit, 46 data points spanning $15.55^{\circ}$ are used to calibrate the Bragg axis.

As a means of evaluating the repeatability, ten spectra were measured for each of the above edges. Data are provided in the supporting information. Standard deviations for the measured positions of EXAFS features of $3.8 \mu \mathrm{rad}$ at the vanadium edge and $1.8 \mu \mathrm{rad}$ at the molybdenum edge were found, high- lighting the excellent repeatability of the monochromator design.

\section{Mirrors}

The beamline focusing comprises a Kirkpatrick-Baez (KB) (Kirkpatrick \& Baez, 1948) mirror pair (ACCEL, Germany), using adaptive bimorph mirror technology (Susini et al., 1995; Cautero et al., 2007) to provide independent horizontal and vertical focusing at any point in the endstation while maintaining operation close to $1: 1$ focusing. Bimorph mirrors have three advantages that make them useful for I22. First, by varying the voltages on individual electrodes, one can correct the waviness left on the mirror surface by polishing, thus achieving a sharp focal spot with small tails. Second, a bimorph responds within seconds to changes in voltage, and even settling times imposed by imperfect mounting of the bimorph generally do not exceed 10-15 min. Therefore, bimorph mirrors permit the size, shape and focal distance of the X-ray beam to be changed rapidly to accommodate different camera lengths. Third, they have good long-term stability, and thus can be left at a constant voltage setting over weeks or months without loss of focal quality. The horizontal focusing mirror (900 mm long, with an $820 \mathrm{~mm}$ active length) and the vertical focusing mirror (600 $\mathrm{mm}$ long, with a $550 \mathrm{~mm}$ active length) are located at $26.8 \mathrm{~m}$ and $27.7 \mathrm{~m}$, respectively, from the source and share a common vacuum vessel. Each mirror substrate is made of fused silica, $50 \mathrm{~mm}$-wide with a central $15 \mathrm{~mm}$-wide coated stripe of rhodium; the stripes provide excellent
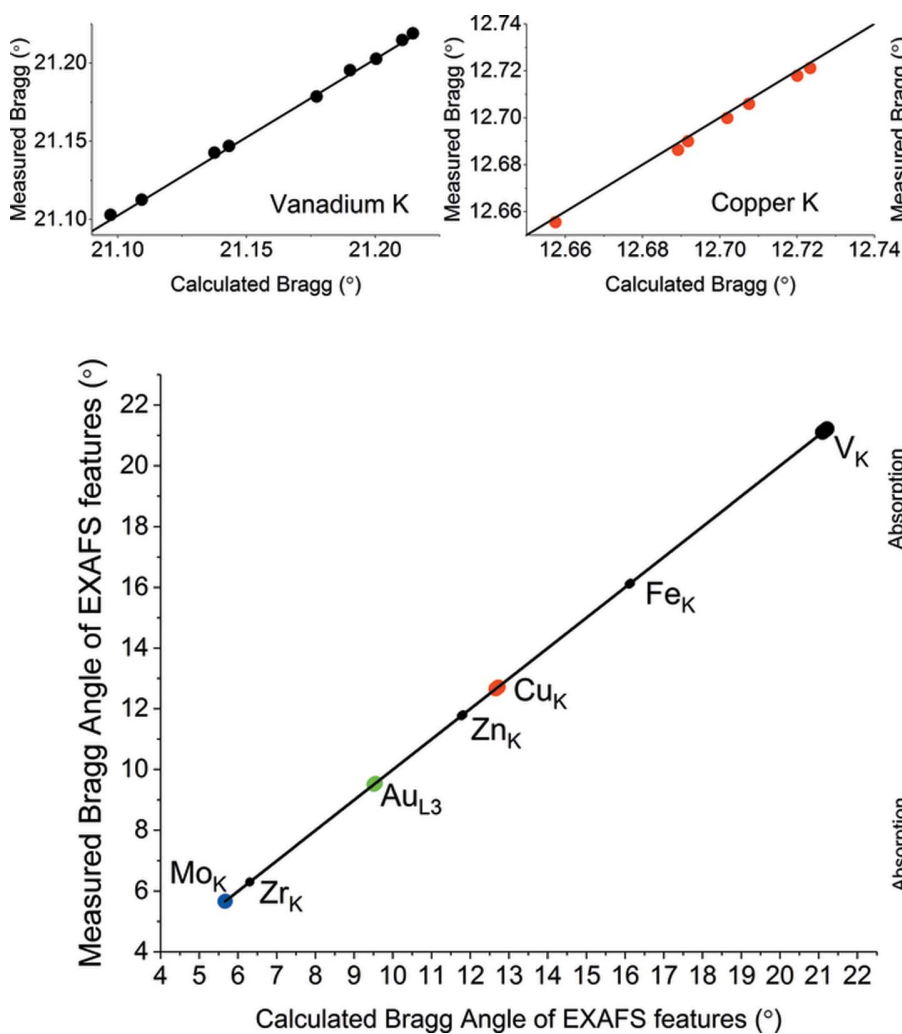
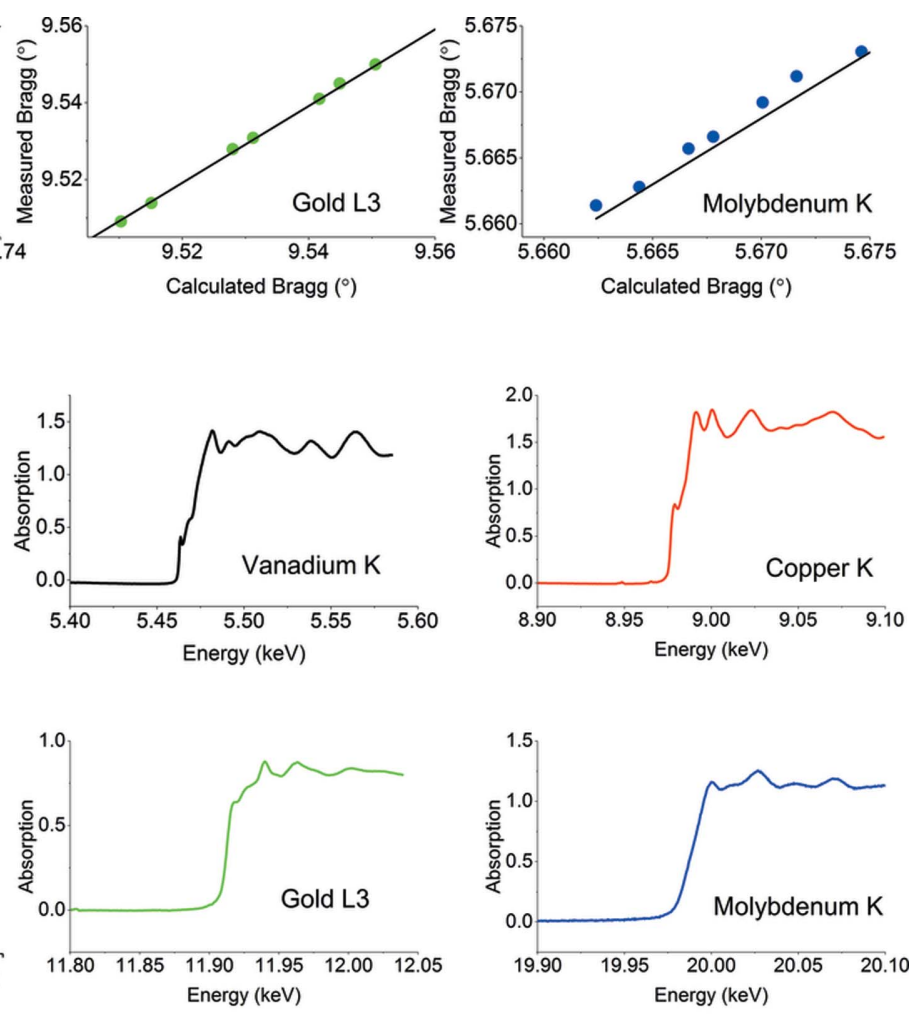

Figure 3

Calibration of the I22 monochromator using EXAFS from metal foils. 
Table 2

Beam sizes for the repolished bimorph mirrors at $12.4 \mathrm{keV}$.

\begin{tabular}{lllll}
\hline & $\begin{array}{l}\text { Demagnified } \\
\text { FWHM } \\
\begin{array}{l}\text { Focal } \\
\text { position }\end{array}\end{array}$ & $\begin{array}{l}\text { H FWHM } \\
\text { slope error } \\
\text { broadening } \\
(\mu \mathrm{m})\end{array}$ & $\begin{array}{l}\text { V FWHM } \\
\text { slope error } \\
\text { broadening } \\
(\mu \mathrm{m})\end{array}$ & $\begin{array}{l}\text { Measured } \\
\text { FWHM } \\
\text { focal size } \\
(\mathrm{H} \times \mathrm{V}, \mu \mathrm{m})\end{array}$ \\
\hline Sample & $258 \times 6$ & 39 & 60 & $262 \times 60$ \\
Sample $+3 \mathrm{~m}$ & $296 \times 7$ & 45 & 69 & $299 \times 69$ \\
Sample $+5 \mathrm{~m}$ & $321 \times 7$ & 49 & 75 & $329 \times 75$ \\
Sample $+7 \mathrm{~m}$ & $346 \times 8$ & 52 & 81 & $350 \times 81$ \\
\hline
\end{tabular}

harmonic rejection across the beamline energy range while operated at $2.6 \mathrm{mrad}$. The adaptive bimorph capability is provided by piezo actuators attached to each substrate. The vertical mirror has 32 electrodes, which are paired along the length to give 16 virtual electrodes. These are used to correct the mirror figure and provide vertical focusing. The horizontal mirror has 12 electrodes, 4 at either end are coupled into 2 pairs and the 4 remaining electrodes are left as singles to give finer control over the central portion of the mirror, where it is of greatest benefit for providing optimal horizontal focusing.

\subsection{Mirror refurbishment}

Examination of the bimorph mirrors using the X-ray beam and the Diamond Light Source nanometre optical metrology (NOM) (Alcock et al., 2010) non-contact profiler revealed damage at the piezo interfaces (Alcock et al., 2013) as indicated by the gross changes in slope error across the mirror in the measurements shown in Fig. 4. Although not all junctions behaved the same (dotted lines in Fig. 4 show the position of the junctions, and features are invariably found near the junctions), these effects translated into poor focusing performance, rendering optimum focusing impossible and causing degradation in beamline background. Repolishing the optical surface of both mirrors significantly improved their focusing capability to the point where optimum focus was achievable.

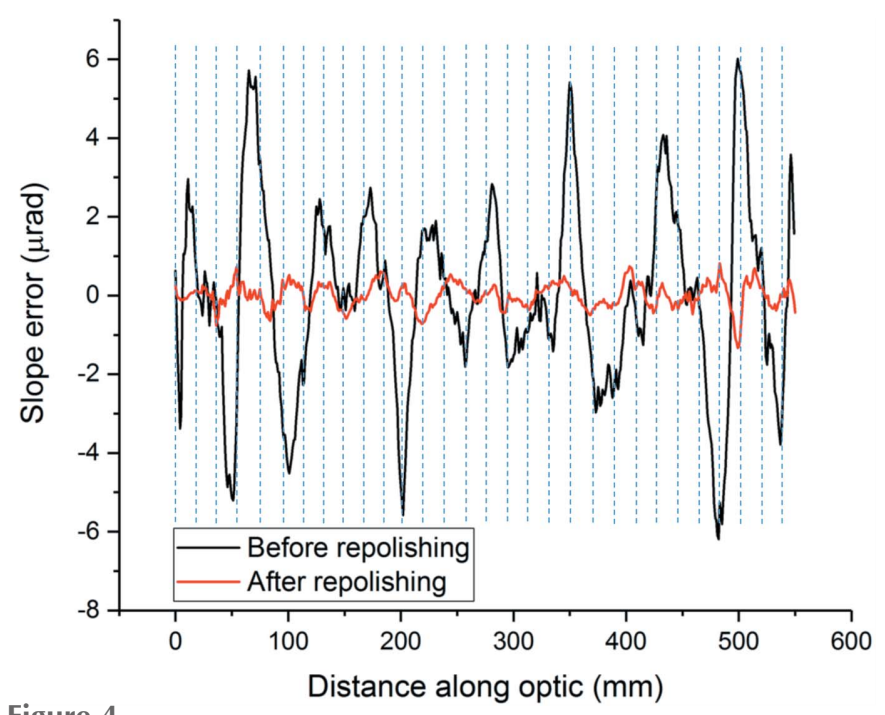

Figure 4

Effect of repolishing the I22 VFM as determined by Diamond NOM.
Table 3

Measured flux, undulator harmonic and undulator gap for commonly used energies.

\begin{tabular}{llll}
\hline $\begin{array}{l}\text { Energy } \\
(\mathrm{keV})\end{array}$ & $\begin{array}{l}\text { Measured flux } \\
\left(\text { photons s }^{-1}\right)\end{array}$ & $\begin{array}{l}\text { Undulator } \\
\text { harmonic }\end{array}$ & $\begin{array}{l}\text { Undulator } \\
\text { gap }(\mathrm{mm})\end{array}$ \\
\hline 7 & $1.08 \times 10^{13}$ & 5 th & 7.035 \\
10 & $6.94 \times 10^{12}$ & 7 th & 7.160 \\
12.4 & $3.97 \times 10^{12}$ & 9 th & 6.921 \\
14 & $2.74 \times 10^{12}$ & 11 th & 6.420 \\
18 & $1.48 \times 10^{12}$ & 17 th & 5.359 \\
\hline
\end{tabular}

Data from the Diamond NOM shows a ninefold improvement in slope error after repolishing from $2.7 \mu \mathrm{rad}$ to $0.3 \mu \mathrm{rad}$.

We stress that the junction effect was not found to appear in the latest 'second-generation' bimorph mirrors, which have their piezoelectric plates attached to the sides of the mirror substrate rather than being sandwiched between an upper and a lower substrate, as is the case with the I22 first-generation bimorph mirrors (Alcock et al., 2019a,b).

Table 2 gives an indication of the beam size at various camera lengths on I22 after correcting the mirror surfaces. These measurements do not perfectly match the theoretical widths. However, with reasonable values of electron beam size and mirror slope error, the theoretical widths come within $16 \%$ of the measured horizontal widths, and $10 \%$ of the measured vertical widths (Table 2).

\section{Endstation}

The endstation on I22 is a versatile space, with a large sample platform that can accommodate a wide range of sample environments. Fig. 5 shows a schematic view of the space, and Fig. S5 of the supporting information shows two sample enviroments mounted side-by-side on the table in a typical experimental configuration.

\subsection{Flux calibration}

Flux values are reported in Table 3 for a selection of commonly used experimental conditions. The measurements were taken using a calibrated diode (Canbera PD-300 PIPS diode calibrated by PTB Berlin) at the sample position.

\subsection{Sample environments}

Samples are mounted on a platform (IDT, Cheshire, UK; customized design) allowing remotely controlled motion of $200 \mathrm{~mm}$ both horizontally and vertically. The platform is mounted on rails for manually controlled motion of $1000 \mathrm{~mm}$ along the beam path. Combined with motorized $X, Y$ and manual $Z$ motion of the WAXS detector nosecone, any reasonable size sample environment can be accommodated whilst minimizing air gaps and attendant background scatter. The sample table surface comprises a standard optical breadboard $(750 \mathrm{~mm} \times 750 \mathrm{~mm}$, M6 tapped holes on a $25 \mathrm{~mm}$ pitch) which facilitates mounting of sample environments, large and small. The platform has $5 \mu \mathrm{m}$ resolution, and can accommodate large sample environments (up to $100 \mathrm{~kg}$ ) 
provided either in-house or built by users. If a small sample environment is required (up to $2 \mathrm{~kg}$ ), such as a single sample cell or lightweight capillary holder, two motorized translation stages equipped with stepper motors (Newport SpectraPhysics Ltd, Didcot, UK; UTS100PP) provide precise sample positioning with $1 \mu \mathrm{m}$ resolution over a $100 \mathrm{~mm}$ range of motion horizontally and vertically. The usual sample environments found on versatile SAXS beamlines are also available on I22. These can be controlled remotely and can trigger - or be triggered - by the data acquisition software. Both Linkam DSC and Capillary furnaces (Linkam Scientific, Surrey, UK) are available for use accessing temperatures in the range $-180^{\circ} \mathrm{C}$ to $550^{\circ} \mathrm{C}$. Two commercial stopped-flow apparatus (SM 400; Bio-Logic, Grenoble, France) specifically designed for synchrotron radiation SAXS are available. One is used for investigations of conformational changes in proteins (Panine et al., 2006), nucleic acids and macromolecules, while the second is dedicated to materials science studies (Lund $e t$ al., 2013). A stress-controlled rheometer (Physica MCR 501; Anton Paar, Hertford, UK) is available with a range of geometries, suitable for a wide range of viscosities ranging from water to polymer melts (Poulin et al., 2016). It can be temperature controlled using air or water, providing an operating range between $-20^{\circ} \mathrm{C}$ and $350^{\circ} \mathrm{C}$. A micromechanical tensile tester has been developed in collaboration with Queen Mary University of London (Karunaratne et al., 2012). This can be used in tension, compression and bending modes. A millisecond pressure-jump cell (1 to 5000 bar) for use in X-ray scattering experiments has been developed in collaboration with Imperial College London, and is now routinely available on I22 (Brooks et al., 2010). For higher pressure, a diamond anvil cell is available for use with the microfocus beam (Almax-easyLab, Diksmuide, Belgium; Boehler-Almax PlateDAC). This cell covers the pressure range $1 \mathrm{GPa}$ to $60 \mathrm{GPa}$.

\subsection{Detectors}

The beamline has a matched pair of Dectris (Dectris AG, Switzerland) Pilatus P3 Hybrid silicon pixel detectors (Henrich et al., 2009), see Table 4. Of particular note is the invacuum $\mathrm{L}$-shaped WAXS detector. This has the basic form of a Pilatus P3-2M with three modules in the lower right corner
Table 4

Detectors available on I22 and their main uses.

\begin{tabular}{ll}
\hline Detector & Use \\
\hline Pilatus P3-2M & (Gi)SAXS data collection \\
& $172 \mu \mathrm{m}$ pixel size \\
& Total active area $254 \mathrm{~mm} \times 289 \mathrm{~mm}$ \\
& Frame rate $250 \mathrm{~Hz}$ with $1 \mathrm{~ms}$ readout \\
Pilatus P3-2M-DLS-L & In-vacuum (Gi)WAXS data collection \\
& $172 \mu \mathrm{m}$ pixel size \\
& Total active area $254 \mathrm{~mm} \times 289 \mathrm{~mm}$ \\
& Frame rate 250 Hz with $1 \mathrm{~ms}$ readout \\
Vortex single element & Fluorescence detection for mapping experiments \\
Silicon pin diode & Absorption correction data collection \\
& $1 \mathrm{~mm}^{2}$ diode embedded in beamstop \\
\hline
\end{tabular}

removed. The detector is built into the vacuum space of the SAXS camera nosecone, affording partial 2D access to WAXS to complement full 2D SAXS in the appropriate configuration. To give the reader an idea of the type of data coverage available in this configuration, silver behenate (a common SAXS standard) has been included in Fig. S4 in the supporting information. With careful beamline set-up, these detectors allow overlap of 1D SAXS and WAXS data over the full camera length capability of the beamline as highlighted by the data shown in Fig 6. The data shown were collected at $12.4 \mathrm{keV}$ with a single $100 \mathrm{~ms}$ frame for both SAXS and WAXS detectors. It is possible to arrange the detectors such that no shadowing of the SAXS detector by the WAXS detector occurs.

\section{Software}

The beamline is controlled using an architecture based on the Experimental Physics and Industrial Control System (EPICS) (Dalesio et al., 1994). A graphical synoptic of the whole beamline is available and windows for specific components can be accessed to set and monitor process variables. Users interact with the beamline through the generic data acquisition client (GDA) (Rees et al., 2010; Gibbons et al., 2011), a software-based data acquisition system that sits on top of the EPICS layer. For simple data collection, frames $\times$ collection length, there are a range of graphical user interfaces available,

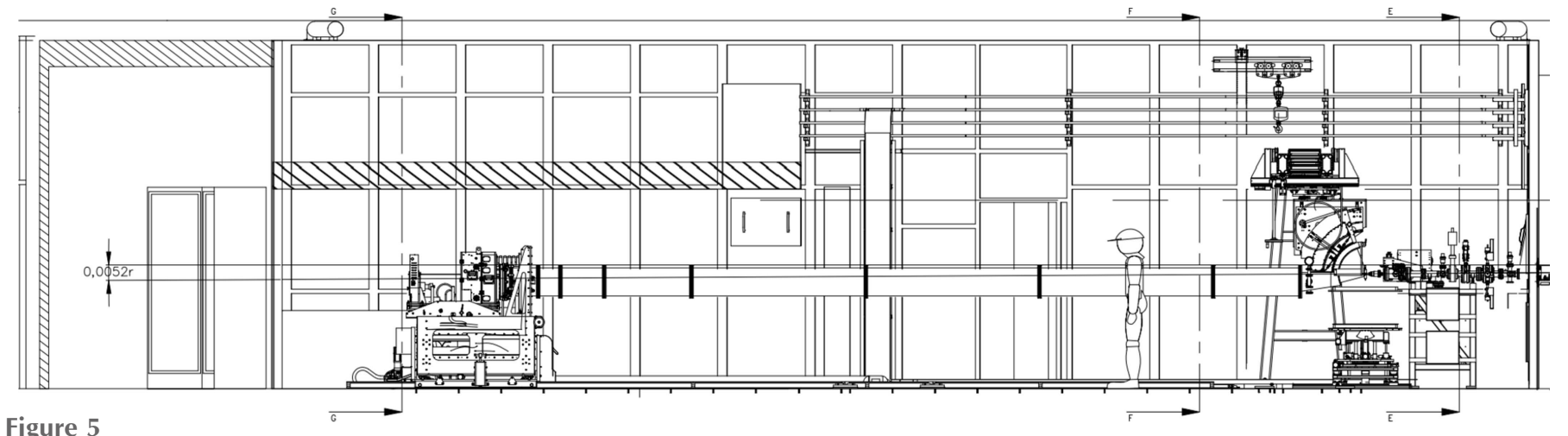

Figure 5

Schematic representation of the I22 endstation. 


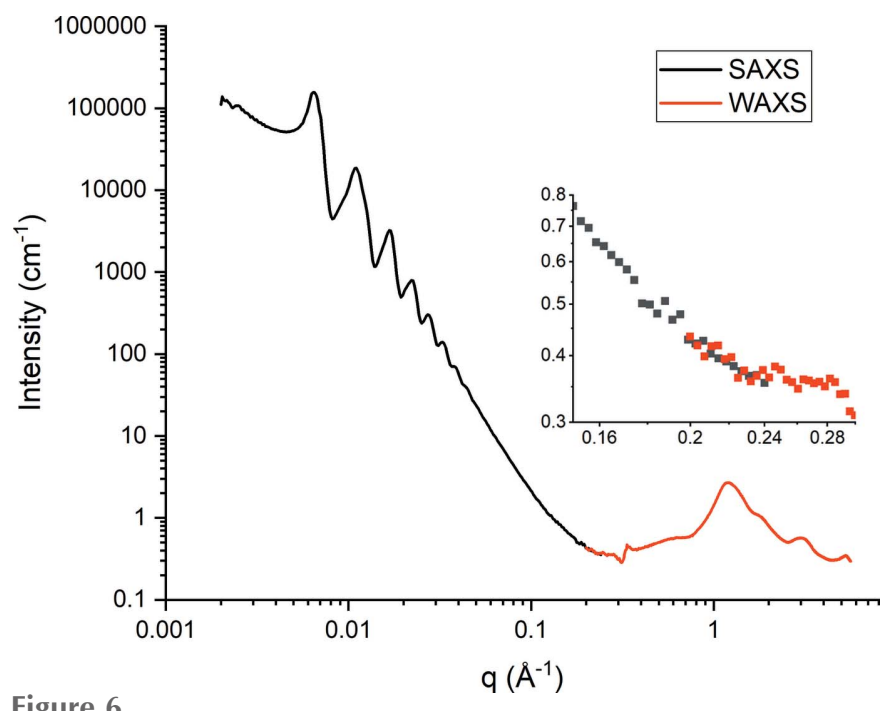

Figure 6

Overlapping $q$-scale of $\mathrm{I} 22$ detectors at $9 \mathrm{~m}$ camera length, the SAXS $q$ scale is $0.002-0.24 \AA^{-1}$, the WAXS $q$-scale is $0.2-5.6 \AA^{-1}$. Data are from $100 \mathrm{~nm}$ silica spheres collected as a powder between two Scotch Tape windows. NB: the inset shows the overlap region in more detail.

and for more complex experiments the full Jython scripting capability of GDA can be employed.

After the acquisition of frame data, by default, GDA triggers any requested analyses that are available through the Data Analysis WorkbeNch (DAWN) software package (Basham et al., 2015; Filik et al., 2017). Most commonly, this analysis entails the reduction of frame data to a one-dimensional dataset of intensity $(I)$ plotted against the scattering wavevector $(q)$ following a standardized schema (Pauw et al., 2017). It is also possible to analyse particular Debye-Scherrer rings, producing $I$ versus azimuthal angle, $\chi$, plots, the calculation of orientation factors and degrees of orientation (Cinader \& Burghardt, 1998; Hermans, 1944) as well as crystallite thickness information from frame data (Fratzl et al., 1996). These scattering-specific analyses are presented alongside a number of other common analytical methodologies, such as function fitting, any number of which can be automatically triggered following data acquisition.

\section{Science examples}

From its inception, I22 was designed to accommodate the wide-ranging scientific requirements of the UK SAXS community. This covers most areas of science from biology and medicine through to advanced materials (O'Sullivan et al., 2011; Inamdar et al., 2017; Tang et al., 2014; Brady et al., 2019; Bots et al., 2014; Besselink et al., 2016; Lutz-Bueno et al., 2016). It has successfully shown its flexibility by accommodating a wide array of diverse sample environments during its years of operation. Some of the more extreme examples have included a complete gold sputter chamber including a full manipulation system, chamber and local computer control hardware for exploring thin-film structure formation (Roth et al., 2015) and a chemical reactor for investigating anoxic calcium carbonate formation (Ahmed et al., 2010). The I22 sample environment portfolio includes many of the standard sample environments you would expect to see at a SAXS/WAXS beamline such as Linkam capillary (Summerton et al., 2018) and DSC furnaces (Castelletto et al., 2018), stop flow devices (Angelov et al., 2011) and commercial rheometers (Wychowaniec et al., 2020).

Of particular note in this area is the P-jump cell developed in collaboration with Imperial College (Brooks et al., 2010). Due to the collaborative development of the cell its functionality has been fully embedded into the beamline control system which has enabled an integrated approach to data collection from the outset. The cell has been in successful operation since 2011 delivering across a range of scientific areas (Bots et al., 2012; Carriero et al., 2014; Balmer et al., 2011; McCarthy et al., 2017; Lehmkühler et al., 2019; Fox et al., 2020) covered by the beamline. We believe that the millisecond pressure jump capability of the cell is unique. An example of exploitation of this capability can be found in a recently published paper on the formation of gold nanoparticle super crystals (Lehmkühler et al., 2019). Utilizing the fast P-jump nature of the cell they were able to demonstrate pressureinduced formation of super crystals from PEGylated gold nanoparticles (see Fig. 7). By varying the pressure, different nanostructures could be prepared.

A paper published recently highlighted the versatility of the cell for studying complex systems. Le Vay et al. (2020) studied the controlled assembly and disassembly of nanoscale protein cages with a view to being able to use the system for capturing active ingredients upon reassembly (see Fig. 8).

The unique combination of a matched pair of Pilatus silicon hybrid pixel detectors for collecting both SAXS and WAXS


Figure 7

Dynamics of gold nanoparticle supercrystal formation. Republished with permission of Royal Society of Chemistry, from Lehmkühler et al. (2019), Phys. Chem. Chem. Phys. 21, 21349-21354; permission conveyed through Copyright Clearance Center, Inc. 

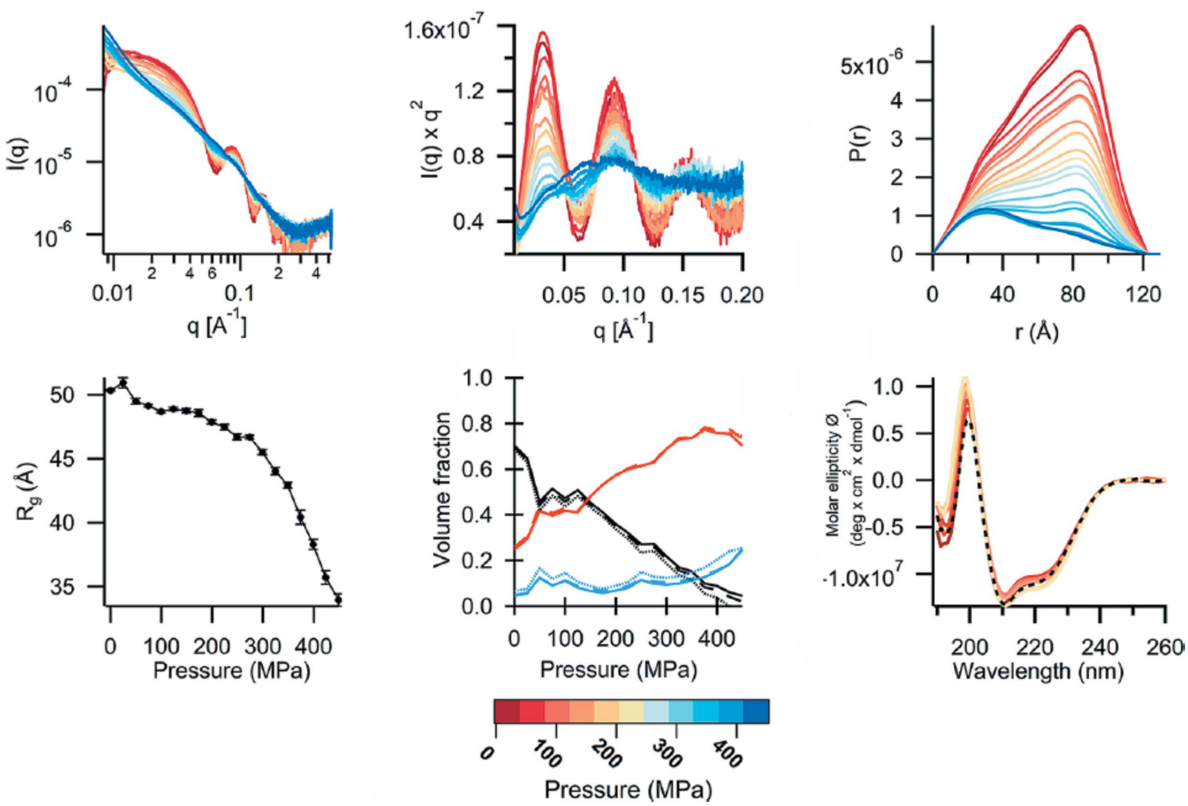

Figure 8

Disassembly/reassembly of bacterioferritin using pressure. Reprinted (adapted) with permission from Le Vay et al. (2020), J. Am. Chem. Soc. 142, 20640-20650. Copyright (2020).



Figure 9

Bassanite crystallization kinetics, highlighting the full $q$-range coverage on I22. Reprinted (adapted) with permission from Stawski et al. (2019), J. Phys. Chem. C, 124, 8411-8422. Copyright (2019) American Chemical Society.

data has also proven useful. Due to the design of the WAXS detector the beamline can collect high-quality SAXS and WAXS data simultaneously over a large solid angle. This has been exemplified by a recent paper on the nucleation pathways of bassanite by Stawski et al. (2020) (see Fig. 9). The overlapping nature of the design, described in Section 6.3, afforded the user group to clearly identify the phases of interest.

\section{Summary}

I22 was designed as a multipurpose, undulator driven, combined SAXS-WAXS facility to serve the needs of a broad

\section{Acknowledgements}

\section{References} 26, 45-51. 87-92.
UK community of SAXS/WAXS users. Therefore, the beamline was designed as a very versatile platform capable of accommodating a wide variety of biological and soft-matter studies. The range of science covered has grown during its operation to include users supported by all of the major UK Science Research Councils as well as European funding bodies and beyond. Being the primary multipurpose SAXS beamline of Diamond, it has been required to carry out work ranging from studying precursors to life on earth (Tang et al., 2014), through selfassembly of polymer thin films (Pearson et al., 2014), to microfocus SAXS mapping studies on bone (Karunaratne et al., 2013) and cornea for a range of medical studies (e.g. Hayes et al., 2013). The selected examples illustrate the potential of the I22 beamline as a highflux, high-resolution X-ray scattering beamline for in situ and time resolved investigations.

We would like to thank the large number of Diamond Light Source personnel, both past and present, that have been involved in the detailed design, build and commissioning of beamline I22 and its components. In particular we would like to thank Alan Bone, Tom Cobb, Alan Day, Alan Grant, Andy Gundry, Ian Johnson, Simon Lay, Pete Leicester, Emily Longhi, Ronaldo Mercado, Brian Nutter, Mark Popkiss, Tobias Richter, Chris Roper, Irakli Sikharulidze, Andy Smith, Richard Staunton-Lambert, Andrew Thompson, Kevin Wilkinson, Joe Williams and Faijin Yuan.

Ahmed, I. A. M., Benning, L. G., Kakonyi, G., Sumoondur, A. D., Terrill, N. J. \& Shaw, S. (2010). Langmuir, 26, 6593-6603.

Alcock, S., Sawhney, K., Scott, S., Pedersen, U., Walton, R., Siewert, F., Zeschke, T., Senf, F., Noll, T. \& Lammert, H. (2010). Nucl. Instrum. Methods Phys. Res. A, 616, 224-228.

Alcock, S. G., Nistea, I.-T., Signorato, R., Owen, R. L., Axford, D., Sutter, J. P., Foster, A. \& Sawhney, K. (2019a). J. Synchrotron Rad.

Alcock, S. G., Nistea, I.-T., Signorato, R. \& Sawhney, K. (2019b). J. Synchrotron Rad. 26, 36-44.

Alcock, S. G., Sutter, J. P., Sawhney, K. J. S., Hall, D. R., McAuley, K. \& Sorensen, T. (2013). Nucl. Instrum. Methods Phys. Res. A, 710,

Al-Jaibaji, O., Swioklo, S., Gijbels, K., Vaes, B., Figueiredo, F. C. \& Connon, C. J. (2018). PLoS One, 13, e0202118.

Angelov, B., Angelova, A., Filippov, S. K., Karlsson, G., Terrill, N., Lesieur, S. \& Stěpánek, P. (2011). Soft Matter, 7, 9714.

Arnold, L. H., Butt, L. E., Prior, S. H., Read, C. M., Fields, G. B. \& Pickford, A. R. (2011). J. Biol. Chem. 286, 45073-45082. 
Balmer, J. A., Mykhaylyk, O. O., Armes, S. P., Fairclough, J. P. A., Ryan, A. J., Gummel, J., Murray, M. W., Murray, K. A. \& Williams, N. S. J. (2011). J. Am. Chem. Soc. 133, 826-837.

Barriga, H. M. G., Law, R. V., Seddon, J. M., Ces, O. \& Brooks, N. J. (2016). Phys. Chem. Chem. Phys. 18, 149-155.

Barrows, A. T., Lilliu, S., Pearson, A. J., Babonneau, D., Dunbar, A. D. F. \& Lidzey, D. G. (2016). Adv. Funct. Mater. 26, 4934-4942.

Basham, M., Filik, J., Wharmby, M. T., Chang, P. C. Y., El Kassaby, B., Gerring, M., Aishima, J., Levik, K., Pulford, B. C. A., Sikharulidze, I., Sneddon, D., Webber, M., Dhesi, S. S., Maccherozzi, F., Svensson, O., Brockhauser, S., Náray, G. \& Ashton, A. W. (2015). J. Synchrotron Rad. 22, 853-858.

Bearden, J. A. \& Burr, A. F. (1967). Rev. Mod. Phys. 39, 125-142.

Bennett, T. D., Tan, J.-C., Yue, Y., Baxter, E., Ducati, C., Terrill, N. J., Yeung, H. H. M., Zhou, Z., Chen, W., Henke, S., Cheetham, A. K. \& Greaves, G. N. (2015). Nat. Commun. 6, 8079.

Besselink, R., Stawski, T. M., Van Driessche, A. E. S. \& Benning, L. G. (2016). J. Chem. Phys. 145, 211908.

Bots, P., Benning, L. G., Rodriguez-Blanco, J.-D., Roncal-Herrero, T. \& Shaw, S. (2012). Cryst. Growth Des. 12, 3806-3814.

Bots, P., Morris, K., Hibberd, R., Law, G. T., Mosselmans, J. F., Brown, A. P., Doutch, J., Smith, A. J. \& Shaw, S. (2014). Langmuir, 30, 14396-14405.

Brady, R. A., Kaufhold, W. T., Brooks, N. J., Foderà, V. \& Di Michele, L. (2019). J. Phys. Condens. Matter, 31, 074003.

Brooks, N. J., Gauthe, B. L., Terrill, N. J., Rogers, S. E., Templer, R. H., Ces, O. \& Seddon, J. M. (2010). Rev. Sci. Instrum. 81, 064103.

Burton, H. E., Eisenstein, N. M., Lawless, B. M., Jamshidi, P., Segarra, M. A., Addison, O., Shepherd, D. E. T., Attallah, M. M., Grover, L. M. \& Cox, S. C. (2019). Mater. Sci. Eng. C, 94, 901-908.

Burton, M. R., Lei, C., Staniec, P. A., Terrill, N. J., Squires, A. M., White, N. M. \& Nandhakumar, I. S. (2017). Sci. Rep. 7, 6405.

Calabrese, V., Muñoz-García, J. C., Schmitt, J., da Silva, M. A., Scott, J. L., Angulo, J., Khimyak, Y. Z. \& Edler, K. J. (2019). J. Colloid Interface Sci. 535, 205-213.

Carriero, A., Zimmermann, E. A., Paluszny, A., Tang, S. Y., Bale, H., Busse, B., Alliston, T., Kazakia, G., Ritchie, R. O. \& Shefelbine, S. J. (2014). J. Bone Miner. Res. 29, 1392-1401.

Castelletto, V., Barnes, R. H., Karatzas, K.-A., Edwards-Gayle, C. J. C., Greco, F., Hamley, I. W., Rambo, R., Seitsonen, J. \& Ruokolainen, J. (2018). Biomacromolecules, 19, 2782-2794.

Cautero, M., Cautero, G., Krastanov, B., Billè, F., Borghes, R., Iviani, L., Cocco, D., Sostero, G. \& Signorato, R. (2007). AIP Conf. Proc. 879, 683-685.

Cinader, D. K. \& Burghardt, W. R. (1998). Macromolecules, 31, 9099 9102.

Coudrillier, B., Campbell, I. C., Read, A. T., Geraldes, D. M., Vo, N. T., Feola, A., Mulvihill, J., Albon, J., Abel, R. L. \& Ethier, C. R. (2016). Invest. Ophthalmol. Vis. Sci. 57, 2666-2677.

Dalesio, L. R., Hill, J. O., Kraimer, M., Lewis, S., Murray, D., Hunt, S., Watson, W., Clausen, M. \& Dalesio, J. (1994). Nucl. Instrum. Methods Phys. Res. A, 352, 179-184.

Dora Tang, T. Y., Rohaida Che Hak, C., Thompson, A. J., Kuimova, M. K., Williams, D. S., Perriman, A. W. \& Mann, S. (2014). Nat. Chem. 6, 527-533.

Filik, J., Ashton, A. W., Chang, P. C. Y., Chater, P. A., Day, S. J., Drakopoulos, M., Gerring, M. W., Hart, M. L., Magdysyuk, O. V., Michalik, S., Smith, A., Tang, C. C., Terrill, N. J., Wharmby, M. T. \& Wilhelm, H. (2017). J. Appl. Cryst. 50, 959-966.

Fox, L. J., Matthews, L., Stockdale, H., Pichai, S., Snow, T., Richardson, R. M. \& Briscoe, W. H. (2020). Acta Biomaterialia, 104, 198-209.

Fratzl, P., Schreiber, S. \& Klaushofer, K. (1996). Connect. Tissue Res. 34, 247-254.

Gibbons, E., Heron, M. \& Rees, N. (2011). Proceedings of the 13th International Conference on Accelerator and Large Experimental Physics Control Systems (ICALEPCS2011), 10-14 October 2011, Grenoble, France, pp. 529-532. TUAAUST01.
Hallett, J. E., Hayward, D. W., Bartlett, P. \& Richardson, R. M. (2014). Liq. Cryst. 41, 1791-1802.

Hayes, S., Kamma-Lorger, C. S., Boote, C., Young, R. D., Quantock, A. J., Rost, A., Khatib, Y., Harris, J., Yagi, N., Terrill, N. \& Meek, K. M. (2013). PLoS One, 8, e52860.

Hayes, S., White, T., Boote, C., Kamma-Lorger, C. S., Bell, J., Sorenson, T., Terrill, N., Shebanova, O. \& Meek, K. M. (2017). J. R. Soc. Interface, 14, 20170062.

Heeley, E. L., Gough, T., Hughes, D. J., Bras, W., Rieger, J. \& Ryan, A. J. (2013). Polymer, 54, 6580-6588.

Henrich, B., Bergamaschi, A., Broennimann, C., Dinapoli, R., Eikenberry, E., Johnson, I., Kobas, M., Kraft, P., Mozzanica, A. \& Schmitt, B. (2009). Nucl. Instrum. Methods Phys. Res. A, 607, 247249.

Hermans, P. H. (1944). Recl Trav. Chim. Pays Bas, 63, 13-24.

Inamdar, S. R., Knight, D. P., Terrill, N. J., Karunaratne, A., CachoNerin, F., Knight, M. M. \& Gupta, H. S. (2017). ACS Nano, 11, 9728-9737.

Kampourakis, T., Ponnam, S., Sun, Y. B., Sevrieva, I. \& Irving, M. (2018). J. Biol. Chem. 293, 14270-14275.

Karunaratne, A., Boyde, A., Esapa, C. T., Hiller, J., Terrill, N. J., Brown, S. D., Cox, R. D., Thakker, R. V. \& Gupta, H. S. (2013). Bone, 52, 689-698.

Karunaratne, A., Esapa, C. R., Hiller, J., Boyde, A., Head, R., Bassett, J. H., Terrill, N. J., Williams, G. R., Brown, M. A., Croucher, P. I., Brown, S. D., Cox, R. D., Barber, A. H., Thakker, R. V. \& Gupta, H. S. (2012). J. Bone Miner. Res. 27, 876-890.

Kirkpatrick, P. \& Baez, A. V. (1948). J. Opt. Soc. Am. 38, 766.

Kudsiova, L., Mohammadi, A., Mustapa, M. F. M., Campbell, F., Welser, K., Vlaho, D., Story, H., Barlow, D. J., Tabor, A. B., Hailes, H. C. \& Lawrence, M. J. (2019). Biomater. Sci. 7, 149-158.

Lehmann, A., Prehm, M., Chen, C., Liu, F., Zeng, X., Ungar, G. \& Tschierske, C. (2018). Chem. Commun. 54, 12306-12309.

Lehmkühler, F., Schroer, M. A., Markmann, V., Frenzel, L., Möller, J., Lange, H., Grübel, G. \& Schulz, F. (2019). Phys. Chem. Chem. Phys. 21, 21349-21354.

Le Vay, K., Carter, B. M., Watkins, D. W., Dora Tang, T., Ting, V. P., Cölfen, H., Rambo, R. P., Smith, A. J., Ross Anderson, J. L. \& Perriman, A. W. (2020). J. Am. Chem. Soc. 142, 20640-20650.

Lund, R., Willner, L. \& Richter, D. (2013). Controlled Polymerization and Polymeric Structures, pp. 51-158. Springer International Publishing.

Lutz-Bueno, V., Zhao, J., Mezzenga, R., Pfohl, T., Fischer, P. \& Liebi, M. (2016). Lab Chip, 16, 4028-4035.

Ma, S., Boughton, O., Karunaratne, A., Jin, A., Cobb, J., Hansen, U. \& Abel, R. (2016). Clin. Rev. Bone Miner. Metab. 14, 150-160.

Mable, C. J., Thompson, K. L., Derry, M. J., Mykhaylyk, O. O., Binks, B. P. \& Armes, S. P. (2016). Macromolecules, 49, 7897-7907.

McCarthy, N., Brooks, N., Tyler, A., ElGamacy, M., Welche, P., Payne, M. \& Chau, P.-L. (2017). Chem. Phys. Lett. 671, 21-27.

McGeehan, J. E., Streeter, S. D., Thresh, S. J., Taylor, J. E., Shevtsov, M. B. \& Kneale, G. G. (2011). J. Mol. Biol. 409, 177-188.

Morgan, S. R., Hieda, O., Nakai, Y., Boote, C., Hayes, S., Kinoshita, S., Meek, K. M. \& Quantock, A. J. (2018). Sci. Rep. 8, 13742.

Neill, T. S., Morris, K., Pearce, C. I., Sherriff, N. K., Burke, M. G., Chater, P. A., Janssen, A., Natrajan, L. \& Shaw, S. (2018). Environ. Sci. Technol. 52, 9118-9127.

O'Sullivan, M. C., Sprafke, J. K., Kondratuk, D. V., Rinfray, C., Claridge, T. D., Saywell, A., Blunt, M. O., O'Shea, J. N., Beton, P. H., Malfois, M. \& Anderson, H. L. (2011). Nature, 469, 72-75.

Panine, P., Finet, S., Weiss, T. \& Narayanan, T. (2006). Adv. Colloid Interface Sci. 127, 9-18.

Patel, Z., George, A., Milward, S., Rial, E. C. M., Rose, A. J., Walker, R. P. \& Williams, J. H. (2017). Proceedings of the 8th International Particle Accelerator Conference (IPAC2017), 14-19 May 2017, Copenhagen, Denmark, pp. 1592-1595. TUPAB116.

Pauw, B. R., Smith, A. J., Snow, T., Terrill, N. J. \& Thünemann, A. F. (2017). J. Appl. Cryst. 50, 1800-1811. 
Pearson, A. J., Wang, T., Dunbar, A. D. F., Yi, H., Watters, D. C., Coles, D. M., Staniec, P. A., Iraqi, A., Jones, R. A. L. \& Lidzey, D. G. (2014). Adv. Funct. Mater. 24, 659-667.

Poulin, P., Jalili, R., Neri, W., Nallet, F., Divoux, T., Colin, A., Aboutalebi, S. H., Wallace, G. \& Zakri, C. (2016). Proc. Natl Acad. Sci. USA, 113, 11088-11093.

Poulos, A. S., Nania, M., Lapham, P., Miller, R. M., Smith, A. J., Tantawy, H., Caragay, J., Gummel, J., Ces, O., Robles, E. S. J. \& Cabral, J. T. (2016). Langmuir, 32, 5852-5861.

Prehm, M., Enders, C., Mang, X., Zeng, X., Liu, F., Ungar, G., Baumeister, U. \& Tschierske, C. (2018). Chem. Eur. J. 24, 1607216084.

Raine, E., Clark, A., Smales, G., Smith, A. J., Gianolio, D., Li, T., Zheng, J., Griffith, B., Hyde, T. I., Feaviour, M., Collier, P., Hanna, J. V., Sankar, G. \& Tsang, S. C. E. (2018). ACS Appl. Nano Mater. 1, 6603-6612.

Rees, N., Garrett, R., Gentle, I., Nugent, K. \& Wilkins, S. (2010). AIP Conf. Proc. 1234, 736-739.

Roth, S. V., Santoro, G., Risch, J. F. H., Yu, S., Schwartzkopf, M., Boese, T., Döhrmann, R., Zhang, P., Besner, B., Bremer, P., Rukser, D., Rübhausen, M. A., Terrill, N. J., Staniec, P. A., Yao, Y., Metwalli, E. \& Müller-Buschbaum, P. (2015). Appl. Mater. Interfaces, 7, 12470-12477.

Salamah, M. F., Ravishankar, D., Kodji, X., Moraes, L. A., Williams, H. F., Vallance, T. M., Albadawi, D. A., Vaiyapuri, R., Watson, K., Gibbins, J. M., Brain, S. D., Perretti, M. \& Vaiyapuri, S. (2018). Blood Advances, 2, 2973-2985.

Seddon, A. M., Richardson, S. J., Rastogi, K., Plivelic, T. S., Squires, A. M. \& Pfrang, C. (2016). J. Phys. Chem. Lett. 7, 1341-1345.

Slatter, D. A., Percy, C. L., Allen-redpath, K., Gajsiewicz, J. M., Brooks, N. J., Clayton, A., Tyrrell, V. J., Rosas, M., Lauder, S. N., Watson, A., Dul, M., Garcia-diaz, Y., Aldrovandi, M., Heurich, M., Hall, J., Morrissey, J. H., Lacroix-desmazes, S., Delignat, S., Jenkins, P. V., Collins, P. W. \& Donnell, V. B. (2018). JCI Insight, 3, e98459.

Stasiak, J., Brubert, J., Serrani, M., Talhat, A., De Gaetano, F., Costantino, M. L. \& Moggridge, G. D. (2015). Soft Matter, 11, 32713278.

Stawski, T. M., Besselink, R., Chatzipanagis, K., Hövelmann, J., Benning, L. G. \& Van Driessche, A. E. S. (2020). J. Phys. Chem. C, 124, 8411-8422.
Sui, T., Sandholzer, M. A., Lunt, A. J., Baimpas, N., Smith, A., Landini, G. \& Korsunsky, A. M. (2014). J. R. Soc. Interface. 11, 20130928.

Summerton, E., Hollamby, M. J., Le Duff, C. S., Thompson, E. S., Snow, T., Smith, A. J., Jones, C., Bettiol, J., Bakalis, S. \& Britton, M. M. (2019). J. Colloid Interface Sci. 535, 1-7.

Summerton, E., Hollamby, M. J., Zimbitas, G., Snow, T., Smith, A. J., Sommertune, J., Bettiol, J., Jones, C., Britton, M. M. \& Bakalis, S. (2018). J. Colloid Interface Sci. 527, 260-266.

Susini, J., Labergerie, D. \& Zhang, L. (1995). Rev. Sci. Instrum. 66, 2229-2231.

Toolan, D. T. W., Adlington, K., Isakova, A., Kalamiotis, A., Mokarian-Tabari, P., Dimitrakis, G., Dodds, C., Arnold, T., Terrill, N. J., Bras, W., Hermida Merino, D., Topham, P., Irvine, D. \& Howse, J. (2017). Phys. Chem. Chem. Phys. 19, 2041220419.

Troilo, H., Barrett, A. L., Zuk, A. V., Lockhart-Cairns, M. P., Wohl, A. P., Bayley, C. P., Dajani, R., Tunnicliffe, R. B., Green, L., Jowitt, T. A., Sengle, G. \& Baldock, C. (2016). Matrix Biol. 55, 49-62.

Wan, C., Heeley, E., Zhou, Y., Wang, S., Cafolla, C., Crabb, E. \& Hughes, D. (2018). Soft Matter, 14, 9175-9184.

Wychowaniec, J. K., Iliut, M., Zhou, M., Moffat, J., Elsawy, M. A., Pinheiro, W. A., Hoyland, J. A., Miller, A. F., Vijayaraghavan, A. \& Saiani, A. (2018). Biomacromolecules, 19, 2731-2741.

Wychowaniec, J. K., Patel, R., Leach, J., Mathomes, R., Chhabria, V., Patil-Sen, Y., Hidalgo-Bastida, A., Forbes, R. T., Hayes, J. M. \& Elsawy, M. A. (2020). Biomacromolecules, 21, 2670-2680.

Xia, S., Metwalli, E., Opel, M., Staniec, P. A., Herzig, E. M. \& Müller-Buschbaum, P. (2018). Appl. Mater. Interfaces, 10, 2982 2991.

Xi, L., De Falco, P., Barbieri, E., Karunaratne, A., Bentley, L., Esapa, C. T., Terrill, N. J., Brown, S. D. M., Cox, R. D., Davis, G. R., Pugno, N. M., Thakker, R. V. \& Gupta, H. S. (2018). Acta Biomater. 76, 295-307.

Zhou, C., Longley, L., Krajnc, A., Smales, G. J., Qiao, A., Erucar, I., Doherty, C. M., Thornton, A. W., Hill, A. J., Ashling, C. W., Qazvini, O. T., Lee, S. J., Chater, P. A., Terrill, N. J., Smith, A. J., Yue, Y., Mali, G., Keen, D. A., Telfer, S. G. \& Bennett, T. D. (2018). Nat. Commun. 9, 5042. 